Socialist Studies / Études socialistes 6(2) Fall 2010: 118-140

Copyright (C) 2010 The Author(s)

SPECIAL SECTION ON ROSA LUXEMBURG'S POLITICAL ECONOMY

\title{
Rosa Luxemburg's Reform or Revolution in the Twenty-first Century
}

HELEN SCOTT

Department of English, University of Vermont. Burlington, Vermont, United States

\begin{abstract}
:
Rosa Luxemburg lived in a time and place very unlike our own. She was part of a mass labour movement with revolutionary socialist politics at its core, during a period when world socialist revolution was a tangible prospect. At the start of the $21^{\text {st }}$ century the United States labour movement is at a historic low point, organized socialist politics lacks a mass working class base, and capitalism brings crisis, war, and environmental destruction across the globe. But nonetheless across the United States, labour activists are confronting the corporate union model with class struggle unionism based on rank and file independence and left politics. Luxemburg's Reform and Revolution, written at a high point of socialist struggle, contains invaluable lessons for this new generation of activists as they confront the political and organizational challenges of the day.
\end{abstract}

\section{Resumé:}

Rosa Luxemburg a vécu à un moment et dans un environnement qui ressemblaient très peu aux nôtres. Elle faisait partie d'un mouvement ouvrier de masse au cœur duquel se situait une politique révolutionnaire socialiste, à une époque où la révolution socialiste mondiale était une possibilité réelle. Au début du 21ième siècle, le mouvement ouvrier aux Etats-Unis a attient un niveau bas historique, la classe ouvrière de masse fait défaut aux politiques socialistes structurées et le capitalisme apporte son lot de crises, de guerres et d'atteintes à l'environnement à travers le monde. Néanmoins, partout aux Etats-Unis, les activistes progressistes font face à des syndicats s'organisant comme des entreprises, et proposent un syndicalisme de lutte des classes basé sur l'indépendance

Helen Scott is an Associate Professor of English at the University of Vermont. She is the editor of The Essential Rosa Luxemburg, published by Haymarket Books, and co-author with Paul Le Blanc of an anthology of Luxemburg's writings, Socialism or Barbarism, from Pluto Press. She has published articles in Callaloo, International Socialist Review, Journal of Haitian Studies, Postcolonial Text, Works and Days, and in several postcolonial collections in addition to her monograph, Caribbean Women Writers and Globalization: Fictions of Independence (Ashgate, 2006). Originally from Britain, she has lived in the US since 1988. She received her BA from the University of Essex and the PhD from Brown University. She is currently a union delegate for United Academics (AFT-AAUP) and is a long time socialist activist in labour and social movements.

Helen Scott est professeur associée d'anglais à l'Université du Vermont. Elle est la rédactrice de The Essential Rosa Luxemburg, publié par Haymarket Books, et co-auteur avec Paul Le Blanc d'une anthologie des écrits de Luxemburg, Socialism or Barbarism, de Pluto Press. Elle a publié des articles dans Callaloo, International Socialist Review, Journal of Haitian Studies, Postcolonial Text, Works and Days, et dans plusieurs collections postcoloniales en plus de sa monographie, Caribbean Women Writers and Globalization: Fictions of Independence (Ashgate, 2006). Originaire de Grande Bretagne, elle vit aux Etats-Unis depuis 1988. Elle a obtenu sa licence à l'Université d'Essex et son doctorat à Brown University. Elle est actuellement répresentant syndicaliste pour United Academics (AFT-AAUP) et une militante socialiste de longue date dans des mouvements ouvriers et sociaux.

Socialist Studies: the Journal of the Society for Socialist Studies/ Études socialistes: Revue de la Société d'études socialistes www.socialiststudies.com

ISSN 1918-2821 
SCOTT: Rosa Luxemburg's Reform or Revolution in the Twenty-first Century

de la base et une politique de gauche. La Réforme et La Révolution, de Luxemburg, écrit à l'un des moments forts de la lutte socialiste, contient des leçons d'une immense valeur pour cette nouvelle génération d'activistes déterminée à faire face aux défis politiques et organisationnels d'aujourd'hui.

Keywords

class struggle $\bullet$ crisis $\bullet$ labour movement $\bullet$ reform $\bullet$ revolution

Mots-clés

lutte des classes $\bullet$ crise $\bullet$ mouvement ouvrier $\bullet$ réforme $\bullet$ révolution

Rosa Luxemburg was both shaped by, and, to an unusual degree, shaped, the historical conditions of her day. The turn of the twentieth century was a period of rapid transformation and political upheaval, as capitalism expanded across the globe. World socialist revolution was, as Georg Lukács put it, an 'actuality,' and Luxemburg participated in two revolutions in her short life. Had she lived, it is a distinct possibility that the fate of the German revolution, and thus of the world, would have been different. This is not to reiterate a version of the 'great man' theory of history, but rather to acknowledge that individuals can and do play pivotal roles within particular social contexts. Within the confluence of events in 1918 Luxemburg and her comrade Karl Liebknecht were valuable leaders with the potential to provide decisive guidance to the revolutionary movement. Instead, they were murdered, and therefore taken out of the equation. Pierre Broué speculates in his history of the German Revolution:

[T] he German Communist Party could have been victorious, even though it was defeated. There does not exist any Book of Destiny, in which the victory of the Russian October and the defeat of the German October, and the victory of Stalin and then Hitler, could have been written in advance. It is human beings who make history $(1971,649)$.

It is important to stress that at the same time that she impacted history as an individual, Luxemburg was inextricably part of the wider working class collective that formed the bedrock of her political environment. Luxemburg, born in Poland, spent most of her adult life working for the Social Democratic Party in Germany, the SPD. Unlike the professional party bureaucrats, who became disconnected from the lives of the majority, Luxemburg stayed in constant contact with workers, from her first experiences in the Polish working class movement, through her early SPD 
work among miners in upper Silesia, through her speaking tours after the 1905 Russian Revolution, to her agitation among fighting workers on the streets of Berlin in the final days of her life.

Paul Le Blanc's description of the social conditions that engendered the Bolsheviks in Russia captures the decisive features of Luxemburg's age: 'The Leninist party came into being within a context: as part of a broad global working-class formation, as part of a developing labour movement, and as part of an evolving labour-radical sub-culture' $(2006,150)$. The politically conscious working class was on the ascendancy; socialism was at the heart of a mass labour movement; and the SPD provided a vital political culture, captured by Mary Nolan in her regional study:

[S]ocial democracy provided a vocabulary for analyzing society and a vision toward which to struggle. It offered a vehicle for coping with urban industrial society and protesting against the inequities of capitalism and political authoritarianism. In the process of filling these functions, social democracy created a political and economic movement and a new kind of workers culture, which brought together thousands of Düsseldorf workers previously divided by skill and occupation, by religion and geographic origin, by experiences and expectations $(1981,3)$.

From the perspective of a socialist living in the United States today, the political environment could hardly be more different. The labour movement, as described, for example, in Kim Moody's recent book US Labour in Trouble and Transition, stands in marked contrast to the confident, combative working class in and around the SPD:

Unions as institutions, with notable exceptions here and there, have failed their members and proved unable to recruit new ones in sufficient numbers to slow down, let alone reverse, a deteriorating balance of class forces in American society that has created a capitalist class of super rich individuals whose wealth is unprecedented in history. The cost of this is a working class that has lost ground in virtually every field of social and economic life $(2007,2)$.

Arguably precisely because the contextual dissimilarities are so marked, Luxemburg's writings continue to be of great value: we can learn much from this highpoint of working class struggle. With the Great Recession of $2008 / 9$ presenting global capitalism with its biggest crisis in generations, the turn of the twenty-first century is also a time of social instability and 
change. ${ }^{1}$ The scale of the crisis led to a renewed interest in Marxism globally, witnessed in the success of the Historical Materialism journal and conference; the publication of Marxist books by mainstream houses; the striking increase in sales of Marx's Das Kapital and the Communist Manifesto; the best-seller status of the proletarian novel Kanikosen; and the celebrity around a Japanese comic version of Das Kapital. In the words of a $\mathrm{BBC}$ report about protests against the G-20 summit in London: 'the economic crisis... made criticizing capitalism acceptable again.' And yet such glimpses of the potential of a revitalized interest in Marxism are nonetheless small, while the relative success of the far right, especially in Europe, is daunting. The project of rebuilding a 'labour radical subculture' is urgent.

In what follows I will consider the central lessons of one of Luxemburg's most significant works, Reform or Revolution, and assess their relevance more than a century later. The context for the debate leading to Luxemburg's Reform or Revolution was the transformation of the SPD from a small revolutionary group operating under conditions of illegality, to a mass political party with representation in the formal political institutions of the day. While a more detailed account is beyond the scope of this article, briefly, the growth of a professional bureaucracy was accompanied by the development of reformist, or revisionist, politics, moving away from the central tenets of revolutionary Marxism. Eduard Bernstein, exiled to England under the Anti-socialist laws (which were repealed in 1890), became one of the main spokespeople of this trend, which developed in to a political tradition that has continued to exert influence, in various guises, throughout the past century. In what follows I shall use Bernstein as the foil for Luxemburg's central arguments, but bearing in mind that both are 'standing in for' larger theoretical traditions. Luxemburg was responding to an attempt to discredit revolutionary Marxism; attacks on Marxism continue to appear with some regularity (Robert Service's Comrades: $A$ History of World Communism, David Priestland's The Red Flag, Archie Brown's Rise and Fall of Communism), and so it seems particularly apt to return to Luxemburg's defense and weigh its continued significance.

\section{Economic crisis}

Bernstein's case against Marx's theory of revolution rests on his apprehension of capitalism's adaptation, through credit, cartels, and

\footnotetext{
${ }^{1}$ See Catherine Rampell's New York Times article for a useful discussion of the origins and popularization of the term 'Great Recession.'
} 
increased productivity, to such a degree that economic crises are no longer inevitable. Referring to the increased regulation of production, Bernstein writes in Evolutionary Socialism: 'Without embarking in prophecies as to its final power of life and work, I have recognised its capacity to influence the relation of productive activity to the condition of the market so far as to diminish the danger of crises' (1899). He further predicted that capitalism, as it was 'tamed' would become more egalitarian and democratic. Such claims have been repeated periodically during capitalism's history. Until recently capitalist economists sounded a lot like Bernstein, repeating the myth that capitalist crises are a thing of the past. As David Leonhardt wrote in the New York Times in early 2008:

Until a few months ago, it was accepted wisdom that the American economy functioned far more smoothly than in the past. Economic expansions lasted longer, and recessions were both shorter and milder. Inflation had been tamed. The spreading of financial risk, across institutions and around the world, had reduced the odds of a crisis. Back in 2004, Ben Bernanke, then a Federal Reserve governor, borrowed a phrase from an academic research paper to give these happy developments a name: 'the great moderation' (Leonhardt, 2008).

Luxemburg's response, in Reform or Revolution and then later in more depth in The Accumulation of Capital, pointed to the inherent contradictions within capitalism that produce crises. She draws attention to three traits of capitalist development on which scientific socialism rests:

First, on the growing anarchy of capitalist economy, leading inevitably to its ruin. Second, on the progressive socialization of the process of production, which creates the germs of the future social order. And third, on the increased organization and consciousness of the proletarian class, which constitutes the active factor in the coming revolution (Luxemburg 1908, 45).

The first of these, capitalism's inevitable 'ruin,' or 'collapse,' has been subjected to many challenges, from Marxist and bourgeois economists alike. Often the critique mirrors the familiar charge leveled at Marxism more generally - the theory is discredited because the predicted collapse has not occurred, in the face of capitalism's ever-new ways to adapt and thrive. Some Marxists, starting with Luxemburg's contemporary Bukharin, have developed a more pointed critique suggesting a too great emphasis on the 'spontaneous collapse' of capitalism. Neither position holds up against Luxemburg's analysis. 
Only willful suppression of Luxemburg's emphasis on the necessity for working class organization - the subjective or 'active' factor in revolution, which I shall come back to-can sustain the allegation that Luxemburg predicted socialism's inevitable triumph. Luxemburg makes no such claim, but rather identifies the inescapable contradictions within the system that present the stark choice between 'socialism or barbarism.' She held that all those measures Bernstein claimed would resolve the problems of young capitalism may defer crises for a period of time, but will ultimately only exacerbate them. Bernstein, she argues, takes the impressionistic and blinkered perspective of the isolated capitalist, but Marxists instead must 'seize these manifestations of contemporary economic life as they appear in their organic relationship with the whole of capitalist development' $(1908,70)$ and thus see the underlying dynamics:

For him, crises are simply derangements of the economic mechanism. With their cessation, he thinks, the mechanism could function well. But the fact is that crises are not 'derangements' in the usual sense of the word. They are 'derangements' without which capitalist economy could not develop at all. For if crises constitute the only method possible in capitalism-and therefore the normal method-of solving periodically the conflict existing between the unlimited extension of production and the narrow limits of the world market, then crises are therefore inseparable from capitalist economy $(1908,71)$.

The ensuing hundred years have confirmed periodic crises as 'the normal method' of resolving capitalism's contradictions. Luxemburg was able to point to two such moments in the years between the publication of Evolutionary Socialism and Reform and Revolution:

Hardly had Bernstein rejected, in 1898, Marx's theory of crises when a profound general crisis broke out in 1900, while seven years later, a new crisis, beginning in the United States, hit the world market. Facts proved the theory of 'adaptation' to be false $(1908,52)$.

A century later we are in the aftermath of the most severe global crisis since the Great Depression of the 1930s; only massive state interventionthe selective abandonment of neoliberalism and return to Keynesianismstemmed market free fall and complete bankruptcy of the financial system. The very measures used to prevent crises, all those credit default swaps and other intricate financial mechanisms, 'aggravated the anarchy of the capitalist world and expressed and ripened its internal contradictions.' And 
the measures taken to halt the Great Recession have in turn created further problems, such as the threat of sovereign debt default, not to mention mass unemployment, exacerbated poverty and human suffering.

Bernstein also rejected the labour theory of value, the premise understood by Marx and also for a long time by bourgeois economists, that labour is embodied in capital, that capitalist profit comes from the exploitation of workers-who are paid less than the value of what they produce-and the excess appropriated by the capitalists as profit. Bernstein moved closer to the marginal utility school of economics, moving away from the identification of labour as the source of all profit, and positing instead an ideal system of supply and demand in a free market system. ${ }^{2}$ This is again reminiscent of the neoliberal mantra that became dominant toward the end of the twentieth century. Luxemburg's response is characteristically vivid:

Bernstein forgets completely that Marx's abstraction is not an invention. It is a discovery. It does not exist in Marx's head but in market economy. It has not an imaginary existence, but a real social existence, so real that it can be cut, hammered, weighed, and put in the form of money. The abstract human labour discovered by Marx is, in its developed form, no other than money $(1908,78)$.

The underlying dynamics emphasized by Luxemburg continue to drive contemporary capitalism: Slashing wages was central to neoliberalism, capitalism's means to recover profitability following the downturn of the mid 1970s. During the economic boom years in the 2000s, the portion of national income going to profits increased dramatically while real wages stagnated. The State of Working America summarized the redistribution of wealth as 'the equivalent of transferring two hundred and six billion dollars annually from labour compensation to capital income' (Mishel 2009, 42):

The stark picture is also emerging at the tail end of a thirty-year cycle in which most workers lost ground even during the supposedly good years. Real hourly wages for the bottom 50 percent of male workers are lower today than they were in 1973, 20 representing a massive shift in wealth toward the wealthiest. On the other hand, the share of national income held by the richest 1 percent doubled, from 9 percent in 1979 to 18 percent in 2005. The transfer accelerated during the last boom. Writes economist Jared Bernstein, between

\footnotetext{
${ }^{2}$ See Kurz, 1995, for a discussion of Bernstein's relationship to the marginal utility school.
} 
2003 and 2005, 'an amazing $\$ 400$ billion in pre-tax dollars was shifted from the bottom 95 percent of households to those in the top 5 percent' (DiLeo 2010, 14).

If capitalism's much debated return to profitability exacerbated class divisions in the United States, the recession has brought unemployment, home foreclosures, and a credit freeze to millions of American workers. While the 'too big to fail' banks received massive infusions of state money, workers got austerity. The scale of poverty and immiseration globally was already horrendous, as seen in studies such as Mike Davis' disturbing Planet of Slums, and the Great Recession just made things a lot worse. Luxemburg's 'barbarism' is more descriptive of our world than Bernstein's 'humane' capitalism.

\section{The Capitalist State}

Bernstein's vision of a gradual transition to socialism rested on the idea that the state would play a crucial role in regulating capitalism and protecting labour, and that political democracy would foster socialist reforms. Luxemburg responds by elaborating a Marxist understanding of the bourgeois state and the limits of bourgeois democracy. Seen in the larger history of successive social forms, capitalism expands the function of the state and develops the political democracy that is to play a vital role in working class struggle. But the fetters of class relationships supersede these progressive features:

The present state is, first of all, an organization of the ruling class. It assumes functions favoring social development specifically because, and in the measure that, these interests and social development coincide, in a general fashion, with the interests of the dominant class $(1908,63)$.

Luxemburg illustrates the conflict between general social good and particular capitalist interests by the examples of tariff barriers and militarism, both of which become indispensable for capitalist nations even as they are incompatible with the overall development of capitalist production:

In the clash between capitalist development and the interests of the dominant class, the state takes position alongside the latter. Its policy, like that of the bourgeoisie, comes into conflict with social development. It thus loses more 
and more its character as a representative of the whole of society and is transformed at the same rate, into a pure class state $(1908,63-4)$.

Luxemburg's analysis was to be confirmed of course in the twentieth century when national competition led to the massive military conflagrations of the two world wars. It also continues to describe our current situation.

While neoliberal ideology insists on the removal of any barriers to international 'free trade,' powerful nations nonetheless do use both tariff and non-tariff controls to protect their own interests, giving themselves a competitive advantage at the expense of others, even when this has damaging global consequences. Within the United States one thinks of tariffs on steel, or subsidies for corn producers, both of which benefit national capital at a cost to those of other nations. The powerful multilateral institutions of the late twentieth century such as the World Trade Organization (WTO), International Monetary Fund (IMF) and World Bank, and trade agreements such as General Agreement on Tariffs and Trade (GATT) and the North American Free Trade Agreement (NAFTA), despite their grandiose claims, infamously enforce the will of the dominant capitalist powers. ${ }^{3}$

The intensification of capitalist globalization led some to prematurely pronounce the end of the nation state, but while neoliberalism insists on dismantling state measures that are beneficial to workers, such as price controls on food, or government spending on health care or education, in other ways the state becomes both stronger and more obviously capitalist. As David Harvey puts it in his study of neoliberalism:

[T] he nationalism required for the state to function effectively as a corporate and competitive entity in the world market gets in the way of market freedoms more generally...the neoliberal state needs nationalism of a certain sort to survive. Forced to operate as a competitive agent in the world market and seeking to establish the best possible business climate, it mobilizes nationalism in its effort to succeed (Harvey 2005 79, 85).

This is the case when capitalism is functioning maximally; when the system is threatened, as in the latest global crisis, states are rapidly and overtly deployed to save national capital. Walden Bello, among others, has drawn attention to these patterns: 'In their responses to the current economic

\footnotetext{
${ }^{3}$ Toussaint, 1998, offers an excellent account of these broad historical processes.
} 
crisis, governments paid lip service to global coordination but propelled separate stimulus programs meant to rev up national markets' (2009). Needless to say, nowhere has this state intervention involved widespread measures beneficial to workers.

Luxemburg famously placed militarism and imperialism at the heart of her analysis of capitalism, and much of her life work was dedicated to opposing war. In Reform or Revolution she outlines the uses of militarism for capitalist nation states:

First, as a means of struggle for the defense of 'national' interests in competition against other 'national' groups. Second, as a method of placement for financial and industrial capital. Third, as an instrument of class domination over the labouring population inside the country (63).

The full weight of Luxemburg's argument is beyond the scope of this article, but what is immediately striking is how accurate her summary remains as a diagnosis of the twenty-first century. The century began with the Pentagon's proclamation of 'full spectrum dominance' - which meant, as William Engdahl puts it, 'that the United States should control military, economic and political developments, everywhere' $(2004,269)$-and has given us protracted wars in Iraq and Afghanistan, the latter now surpassing the official duration of the Vietnam war. In addition, United States Special Forces now operate in around seventy-five countries, as part of the 'war on terror' in the Middle East, central Asia and Africa. These conflicts stem from broader maneuvering between world powers-the United States, Europe, Japan, China-as much as the drive for direct control of oil and gas supplies, and other precious resources, such as those recently 'discovered' by the Pentagon in Afghanistan. And on a global scale also this century continues to see militaries used against domestic 'labouring populations' when they protest, from Egypt to Greece to Thailand.

\section{Bourgeois democracy}

This bolsters Luxemburg's objection to Bernstein's prediction that capitalism as it matured would necessarily deepen and spread bourgeois democracy. Luxemburg responded: 'No absolute and general relation can be constructed between capitalist development and democracy' (86). This can be seen today both in the existence of capitalist nations that are not formally democracies, and in the severe limitations of actual democracy within those that are. While capitalism is assumed to be reciprocal with 
democracy in dominant ideological formulations, bourgeois apologists for authoritarianism are not uncommon. In one of his regular op-ed pieces for the New York Times David Brooks recently mapped out the division between 'democratic' and 'state' capitalist regimes, suggesting that sometimes the latter may be necessary, and conversely sometimes democracy can stand in the way of the profit motive:

[S]tate capitalism may be the only viable system in low-trust societies, in places where decentralized power devolves into gangsterism. Moreover, democratic regimes have shown their vulnerabilities of late: a tendency to make unaffordable promises to the elderly and other politically powerful groups; a tendency toward polarization, which immobilizes governments even in the face of devastating problems (Brooks, 2010).

For some liberals the contradiction is so blatant that they seek to understand, like Robert Reich, why capitalism is 'killing democracy:'

Capitalism, long sold as the yin to democracy's yang, is thriving, while democracy is struggling to keep up. China, poised to become the world's third largest capitalist nation this year after the United States and Japan, has embraced market freedom, but not political freedom. Many economically successful nations - from Russia to Mexico-are democracies in name only. They are encumbered by the same problems that have hobbled American democracy in recent years, allowing corporations and elites buoyed by runaway economic success to undermine the government's capacity to respond to citizens' concerns (Reich 2007, 38-9).

Reich sees this antagonism as both anomalous and something that can be corrected; Luxemburg shows it to be systemic and inescapable. She points out that bourgeois political and legislative systems are products of bourgeois revolution: 'Every legal constitution is the product of a revolution. In the history of classes, revolution is the act of political creation, while legislation is the political expression of the life of a society that has already come into being' $(2008,89)$. And further, capitalist rule is distinct from previous forms of class rule because it is expressed economically:

What distinguishes bourgeois society from other class societies - from ancient society and from the social order of the Middle Ages? Precisely the fact that class domination does not rest on 'acquired rights' but on real economic relations - the fact that wage labour is not a juridical relation, but purely an 
economic relation. In our juridical system there is not a single legal formula for the class domination of today (90).

The capitalist 'bias' in politics is more than simply the existence of corporate lobbying, funding of candidates, and the presence of corporate executives in office and vice versa (though these are admittedly overwhelming): the fundamental class relations are the bed rock of capitalist society, not limited to the legal or political superstructure.

This is something that has been exposed by the British Petroleum (BP) Deepwater Horizon oil spill in the Gulf of Mexico, a colossal environmental catastrophe where corporate power is blatantly at odds with public and environmental welfare, and government regulation is all but non-existent. The interpenetration of government and corporate power is visible in everything from the regulation agencies which rubberstamped BP's plans, to the industry interests of individual members of the investigative commission (Republican William K. Reilly, formerly of the Environmental Protection Agency, board member of ConocoPhillips, DuPont, and Energy Future Holdings) or judges (Martin Feldman, with an investment history in Transocean, Halliburton, and others). This event has led some left commentators, such as Paul Street, to revisit the Marxist critique of bourgeois democracy:

It might seem a 'paradox' that the rise of large scale industrial capitalist tyranny-characterized by the massive top-down command and systematic exploitation of labour and related gross, authoritarian, democracy-disabling economic inequality-coincided with the expansion of formal democracy (universal suffrage, free political parties and associations and speech, etc.) across the West. (Street, 2010)

Street cites Ellen Meiksins Wood's 1995 book, Democracy Against Capitalism: 'Capitalism, she observed, is different from previous and other class systems and modes of production...in that it is characterized by a fundamental division between the political and the economic' (Street 2010). Luxemburg's systemic analysis is more pertinent now than a century ago, while Bernstein's prediction that democracy would consistently spread as capitalism developed seems hopelessly naïve and outdated. 


\section{Socialism From Below}

The difference between Bernstein and Luxemburg again can be located in the latter's materialist method that mitigates against the former's impressionism. While Bernstein accepts the appearance of a neutral state, Luxemburg always keeps in mind the inescapable underlying class antagonism. Luxemburg responds to Bernstein's impatience with Marx's 'dualism:'

What is Marx's 'dualism' if not the dualism of the socialist future and the capitalist present? It is the dualism of capitalism and labour, the dualism of the bourgeoisie and the proletariat. It is the scientific reflection of the dualism existing in bourgeois society, the dualism of the class antagonism writhing inside the social order of capitalism (79).

Luxemburg consistently takes the perspective of the oppressed class, while Bernstein, in his acceptance of the universality of capitalist society, takes that of the bourgeoisie:

[Bernstein] thinks he succeeds in expressing human, general, abstract science, abstract liberalism, abstract morality. But since the society of reality is made up of classes, which have diametrically opposed interests, aspirations, and conceptions, a general human science in social questions, an abstract liberalism, an abstract morality, are at present illusions, pure utopia. The science, the democracy, the morality, considered by Bernstein as general, human, are merely the dominant science, dominant democracy, and dominant morality, that is bourgeois science, bourgeois democracy, bourgeois morality (1908, 98-9).

That Bernstein sides with the ruling class accounts also for his elitism and palpable distaste for workers. In Evolutionary Socialism he writes:

We cannot demand from a class, the great majority of whose members live under crowded conditions, are badly educated, and have an uncertain and insufficient income, the high intellectual and moral standard which the organisation and existence of a socialist community presupposes (Bernstein, 1899).

Bernstein can only imagine reforms as the act of the enlightened few, such as himself, and Social Democratic representatives in government: he 
anticipates the 'socialism from above' described by Hal Draper more than half a century later in his Two Souls of Socialism:

What unites the many different forms of Socialism-from-Above is the conception that socialism (or a reasonable facsimile thereof) must be handed down to the grateful masses in one form or another, by a ruling elite which is not subject to their control in fact.

Luxemburg embodies the other side of the equation:

The heart of Socialism-from-Below is its view that socialism can be realized only through the self-emancipation of activized masses 'from below' in a struggle to take charge of their own destiny, as actors (not merely subjects) on the stage of the history. "The emancipation of the working classes must be conquered by the working classes themselves:" this is the first sentence in the rules written for the First International by Marx, and this is the First Principle of his life-work.

Luxemburg insists on 'the conquest of political power by a great conscious popular mass' (95), not as a minority act 'on behalf of' the working class.

\section{The Labour of Sisyphus}

These polar positions are played out in Luxemburg's discussion of trade unions. The reformist position was captured by Konrad Schmidt, who predicted that 'the trade-union struggle for hours and wages and the political struggle for reforms will lead to a progressively more extensive control over the conditions of production,' and 'as the rights of the capitalist proprietor will be diminished through legislation, he will be reduced in time to the role of a simple administrator' (quoted in Luxemburg, 1908, 55). Schmidt's error, Luxemburg explains, is in mistaking superficial gains for labour, such as wage increases or limits on the working day, as 'social controls' that are little pieces of socialism. But in fact, while unions may negotiate the terms of wages and exploitation in isolated incidences, 'trade unions cannot suppress the law of wages...They have not...the power to suppress exploitation itself', not even gradually:

[T] he scope of trade unions is limited essentially to a struggle for an increase of wages and the reduction of labour time, that is to say, to efforts at regulating capitalist exploitation as they are made necessary by the momentary situation of the world market. But labour unions can in no way influence the process of production itself $(1908,57)$. 
Where reformists see increasing potential for long term permanent gains for workers through reforms, Luxemburg instead sees the limitations: 'the fact is that trade unions are least able to execute an economic offensive against profit. Trade unions are nothing more than the organized defense of labour power against the attacks of profits' $(1908,82)$. While trade unions can give workers bargaining power in specific instances over wages and conditions, these gains are partial, and have to be won over and over again. Luxemburg captured this reality in the famous metaphor comparing union work to the labour of Sisyphus, the mythological king doomed to repeatedly roll a huge stone to the top of a hill only to see it roll back down again. Ultimately trade unions have no power over the capitalist mode of production itself.

The intervening century in the United States has certainly confirmed this judgment, with periods of immense gains for organized labour such as in the 1930s, but then periods of defeats, such as the 1980s. One hundred years later, the fundamental rights being fought for at the turn of the $20^{\text {th }}$ century- the eight-hour workday, abolition of homework and piecework, complete observance of Sunday rest, recognition of the right to unionize-are still not possessed by workers in the most advanced capitalist nations. To take one example of many, Upton Sinclair famously documented the atrocities of the meat packing industry in Chicago in 1906; those abuses were largely wiped out after decades of labour activism. But in the wake of the de-unionization of the meat industry, many of the same conditions have returned to the plants now located in the mid-west and employing Asian and Latino rather than Eastern European immigrants. And of course in 'low wage' factories in Mexico and China-and, due to the criminalization of immigrants, in sectors of industry within the United States-workers face conditions akin to those of England's early industrial revolution.

Luxemburg's grasp of trade unions' powerlessness to tame capitalism is accompanied by an appreciation nonetheless of their necessity, and a strategy for trade union work that has profound implications for labour activists today. Luxemburg makes a crucial distinction between a revolutionary approach (which she identifies as the official SPD position) and a reformist approach (seen in Bernstein and his allies, and in the trade union bureaucracy), to trade union and more broadly political labour work: 
According to the present conception of the party, trade-union and parliamentary activity are important for the socialist movement because such activity prepares the proletariat, that is to say, creates the subjective factor of the socialist transformation, for the task of realizing socialism. But according to Bernstein, trade-union and parliamentary activity gradually reduce capitalist exploitation itself. They remove from capitalist society its capitalist character. They realize objectively the desired social change (66).

Luxemburg elaborates an approach taken by the trade-union officialdom in The Mass Strike:

The specialization of professional activity as trade-union leaders, as well as the naturally restricted horizon that is bound up with disconnected economic struggles in a peaceful period, leads only too easily, among trade-union officials, to bureaucratism and a certain narrowness of outlook (Mass Strike 177).

Luxemburg further identifies 'the overvaluation of the organization, which from a means has gradually been changed into an end in itself,' an 'openly admitted need for peace, which shrinks from great risk and presumed dangers to the stability of the trade unions,' 'the overvaluation of the tradeunion method of struggle itself,' and the tendency to 'lose the power of seeing the larger connections and of taking a survey of the whole position' (177). All of this leads to a narrow focus on 'economic' issues and the pursuit of political 'neutrality.'

Now on the one hand Luxemburg is engaging in a time and place specific polemic against the increasingly powerful bureaucracy within the new and massive legal union movement in Germany, but on the other hand much of what she elaborates is much more broadly applicable. The union movement within the United States has moved through its own specific history, experiencing extreme lows and heights of strength and influence. The post world war two period both witnessed the high point of union membership (33\% of the workforce in the 1950s), but also the development of business unionism and with McCarthyism, purging of communists and socialists from the movement. While labour-management 'cooperation' once accompanied high wages and good benefits within unionized industries, capital's offensive from the mid 1970s led to a steady decline in unionization and weakening of labour's bargaining power to its current low point (12\% of the workforce today), as described by Kim Moody: 
The quarter century-old retreat that followed the turning point of the early 1980s has left a trail of declining living and working standards for union and nonunion workers alike. It has turned collective bargaining on its head-from a front for economic and social gains across a broad range of issue to a means of retreat, sometimes orderly, sometimes not. Far from taming the lion of employer aggression, it has encouraged still more demands for lower labour costs and the slumping living standards that follow (Moody 2007, 2).

In the wake of these developments, the $21^{\text {st }}$ century American labour movement is characterized by starkly opposing strategies: what Moody calls 'bureaucratic corporate unionism,' taking the long dominant tactics of business unionism - a top down organizational model, labourmanagement cooperation, concessionary bargaining - to new levels:

This new direction is a step beyond business unionism in its centralization and shift of power upward in the union's structure away from the members, locals, and workplace; its fetish with huge administrative units; and its almost religious attachment to partnerships with capital. We call it corporate unionism because its vision is essentially administrative, its organizational sensibility executive rather than democratic, and its understanding of power market-based and, hence, shallow (196).

And against this is what is variably called 'social movement' or 'social justice' or 'class struggle' unionism, espoused by rank and file labour activists scattered throughout workplaces across the country: the 'democratic social movement unionism born of struggle with the employers' (197).

Bureaucratic unionism distrusts the membership, appeals to an imaginary 'lowest common denominator,' avoids 'controversial' political stances, and sees union activity in itself as the end. Social justice unionism, in contrast, often emerges from, or is strengthened by, political issues outside of specific workplaces. The 'Day Without Immigrants' actions of May 12006 featured widespread strikes and mass protests bringing millions out on to the streets across the United States of America. While certainly workplace issues and demands contributed, the primary source of this activism was the struggle to defend and extend immigrant rights. The epic battle of the National Union of Healthcare Workers in California against the bureaucratized Service Employees International Union (SEIU) stems as much from a desire for democracy, transparency, and worker control within the union as it does from workplace issues. Social 
movement unionism is also making itself felt in the workforce with the highest percentage of unionization in the nation: public teachers. The official leadership of the National Education Association (NEA) and the American Federation of Teachers (AFT) hew to a well-worn bureaucratic approach, oriented to the Democratic Party and accepting the terms of budget cuts and attacks on teachers in the name of 'accountability' and test scores. But a new reform movement within the teachers' unions is challenging this orthodoxy. The recent election victory for the Caucus of Rank-and-File Educators (CORE) group in Chicago stemmed from an alternative strategy that goes beyond the immediate workplace to consider larger political questions, and to build solidarity with students and parents. ${ }^{4}$ Reform or Revolution contains invaluable lessons for this new generation of labour activists.

\section{Reform or Revolution}

Luxemburg insists that socialists cannot 'counterpose' reform and revolution, but that rather there is an 'indissoluble tie' between the two, the struggle for reforms being an essential means to the end of revolutionary transformation. Bernstein reversed the Marxist equation when he declared: 'The final goal, no matter what it is, is nothing; the movement is everything.' Luxemburg shows that another crucial substitution has also taken place:

People who pronounce themselves in favor of the method of legislative reform in place and in contradistinction to the conquest of political power and social revolution do not really choose a more tranquil, calmer, and slower road to the same goal, but a different goal. Instead of taking a stand for the establishment of a new society they take a stand for surface modifications of the old society (90).

The reformist strategy thus throws out the possibility of revolution; it is also less able to actually win reforms. And when social democracy comes to power in government, it will only be able to manage the system, not change it. The record of social democracy in office throughout the twentieth century has repeatedly confirmed Luxemburg's analysis, from Germany's SPD in world war one through to Britain's New Labour at century's end.

\footnotetext{
${ }^{4}$ The election speech by new president Karen Lewis can be read in the CORE newsletter: http://coreteachers.com/2010/06/13/karen-lewis-ctu-president-elect-acceptance-speech/
} 
One of Luxemburg's claims that is obviously incorrect is her optimistic comment that 'Bernstein's theory was the first, and at the same time, the last attempt to give a theoretic base to opportunism' (102); instead countless versions have replaced his. In the United States in the absence of any major socialist or labour party, the Democrats have long claimed the mantel of 'party of the people' and, in the words of Lance Selfa, 'played the role of the party that appeals to immigrants, the oppressed, and working-class Americans with the promise of policies that increase economic and social opportunity,' while in fact functioning as the 'graveyard of social movements' (Selfa 2008, 9). Many of Luxemburg's arguments again are of great value in understanding the role of the Democrats: the class character of the state, legal, and political systems; the fact that oppression and inequality are embedded in capitalism; the dominance of bourgeois ideas.

But perhaps the most pertinent of all is Luxemburg's identification of the fundamental elitism at the heart of reformism, its assumption that only a professional minority can achieve reforms 'on behalf of' the oppressed masses. The same logic is at work in the argument that only through electing a Democrat can workers achieve union rights, defend access to abortion, secure immigrant protections, or safeguard the environment. Luxemburg's response, that only the 'popular masses themselves, in opposition to the ruling classes' can transform capitalist society (102) has been confirmed over time. Certainly every major progressive reform won in the course of the century in the United States was the result of independent grass roots mass movements. As the late Howard Zinn was wont to say, 'the really critical thing isn't who is sitting in the White House, but who is sitting in.' And globally major structural shifts, such as the overthrow of apartheid in South Africa, or the neoliberal rebellion across Latin America, have been the result of mass working class activity.

The material preconditions for socialist revolution emphasized by Luxemburg are more prevalent now than in her lifetime: the global working class is far bigger and more productive than in Luxemburg's day; the socialization of production has intensified as capitalism has become more globalized and interlocked; 'just in time' production makes capitalism particularly vulnerable to strike action. Now a group of workers in one plant or region can have a disproportional impact on a large-scale operation. In just this way the recent strike of 2000 workers at a Honda components manufacturing plant in Foshan shut down all of the multinational's plants across China. 
The 'increased organization and consciousness of the proletarian class, which constitutes the active factor in the coming revolution' (45) did not grow steadily, culminating in world revolution in a short time frame. Luxemburg always stressed that this was not a foregone conclusion:

[1]t is impossible to imagine that a transformation as formidable as the passage from capitalist society to socialist society can be realized in one happy act...Socialist transformation supposes a long and stubborn struggle, in the course of which, it is quite probable, the proletariat will be repulsed more than once (95).

The heightened inequalities stemming from the Great Recession have provoked mass working class responses in countries as far apart as Guadeloupe, Iceland, Thailand, and France. The celebrated trends predictor Gerald Celente was widely quoted for his account of the fallout: 'This is a 21st century rendition of the "workers of the world unite". The people are fully aware of the enormous bailout going to the 'too big to fails' that they are being forced to pay for. The higher the taxes go, the more jobs that are lost, the greater the levels of protest' (Amies 2010).

\section{Socialism or Barbarism.}

The scale and depth of the crises rocking our globe return us to Luxemburg's stark opposition. As Paul Street put it recently:

The barbarism has already begun and the fight is now both against that and for mere survival. The corporate state is leading us on a death march at an everescalating pace. Deepwater and Bhopal are us. It will not do to tinker around the edges in response. Only revolution can save the Earth (Street, 2010).

Capitalism is routinely presented as inevitable, natural, and superior throughout all major social institutions in the United States of America. As Robert McChesney and John Bellamy Foster write: 'Perhaps nothing points so clearly to the alienated nature of politics in the present day United States as the fact that capitalism, the economic system that drives the society, is effectively off-limits to critical review or discussion' (McChesney 2010). And yet people's experiences inevitably collide with the ideology. Polls from Pew Research Center, Gallup, and Rasmussen suggest increasingly unfavorable attitudes towards capitalism: only a slim majority report a positive view of capitalism, while from twenty per cent to more than a third report a positive view of socialism. Clearly the definition of 
'socialism' here is highly variable, and none of these results demonstrate a mass turn to Marxist politics. But they do indicate that large numbers of Americans reject the idea repeated daily that capitalism is the best and the only imaginable social system. And periodically that dissatisfaction translates in to collective action: the factory occupation by workers at Republic Windows and Doors; the Equality Across America protests; the March $4^{\text {th }}$ day of action for public education in California and elsewhere.

Kim Moody concludes US Labour in Trouble and Transition with the possibility of a renewed movement: 'The hope for the next upsurge is that there is a clearer vision with a wide enough base and an experienced grassroots leadership to push beyond the limits of the ideology, practice, and personnel of business unionism in its old and new forms' (246-7). If the long period of working class defeat is to be reversed, the lessons of our revolutionary history must be learned again. Luxemburg describes the task of socialists:

The union of the broad popular masses with an aim reaching beyond the existing social order, the union of the daily struggle with the great world transformation, that is the task of the social democratic movement, which must logically grope on its road of development between the following two rocks: abandoning the mass character of the party or abandoning its final aim, falling into bourgeois reformism or into sectarianism, anarchism, or opportunism (102-3).

Socialists working in our very different environment must help rebuild the 'labour-radical sub-culture:' participate in struggles where they break out, and bring Marxist ideas and history with them. The works of Rosa Luxemburg have much to teach us in this ongoing process.

\section{References}

Amies, Nick and Michael Knigge. 2010. 'Experts fear spread of social unrest as financial crisis continues.' Deutsche Welle 26 May. http://www.dwworld.de/dw/article/0,,5547861,00.html

Bello, Walden. 2009. 'The Virtues of Deglobalization.' Huffington Post. Sept 5. http://www.huffingtonpost.com/walden-bello/the-virtues-ofdeglobaliz_b_277531.html

Bernstein, Eduard. 1899. Evolutionary Socialism. Marxists Internet Archive. http://www.marxistsfr.org/reference/archive/bernstein/works/1899/evsoc/ch 02-2.htm 
Brooks, David. 2010. 'The Larger Struggle.' New York Times. June 14. http://www.nytimes.com/2010/06/15/opinion/15brooks.html

Broué, Pierre. 1971. The German Revolution 1917-1923. Chicago: Haymarket.

Cox, Judy. 2003. 'Can Capitalism Go On Forever? A Review of Rosa Luxemburg, The Accumulation of Capital' International Socialist Journal 100. Autumn. http://www.isj.org.uk/index.php4?id=8\&issue $=100$

Davis, Mike. 2006. Planet of Slums. London: Verso.

DiLeo, Petrino. 2010. 'The Jobless Recovery: A Lost Decade for Workers?' International Socialist Review 69: 12-18.

Draper, Hal. 1968. Socialism From Below. New York: ARS.

Engdahl, William. 2004. A Century of War: Anglo-American Oil Politics and the New World Order. Revised Edition. London: Pluto.

Foster, John Bellamy. 2006. Naked Imperialism: The U.S Pursuit of Global Dominance. New York: Monthly Review Press.

Gallup. 2010. 'Socialism Viewed Positively by $36 \%$ of Americans.' February 4. http://www.gallup.com/poll/125645/socialism-viewed-positivelyamericans.aspx

Harvey, David. 2005. A Brief History of Neoliberalism. Oxford: Oxford UP.

Kurz, Heinz. 1995. 'Marginalism, Classicism and Socialism in German Speaking Countries 1871-1932.' Ian Steedman, ed. 1995. Socialism and Marginalism in Economics 1870-1930. London: Routledge.

Le Blanc, Paul. 2006. Marx, Lenin, and the Revolutionary Experience. New York: Routledge.

Leonhardt, David. 2008. 'Worries that the Good Times Were Mostly a Mirage.' New York Times. 23 January http://www.nytimes.com/2008/01/23/business/ 23leonhardt.html

Lukács, Georg. 1924. Lenin: A Study on the Unity of His Thought. Cambridge: MIT Press.

Luxemburg, Rosa. 1908. Reform or Revolution. In Scott (ed), 2008: 41-104.

Luxemburg, Rosa. 1906. The Mass Strike, the Political Party, and the Trade Unions. In Scott (ed), 2008: 111-181.

McChesney, Robert W. and John Bellamy Foster. 2010. 'Capitalism, the Absurd System: A View from the United States.' Monthly Review 62, No 2, June. http://monthlyreview.org./100601mcchesney-foster.php 
Mishel, Lawrence, Jared Bernstein and Heidi Shierholz. 2009. The State of Working America 2008/2009. Washington: Economic Policy Institute.

Moody, Kim. 2007. US Labour in Trouble and Transition: the Failure of Reform From Above, the Promise of Revival from Below. London: Verso.

Nolan, Mary. 1981. Social Democracy and Society: Working-Class Radicalism in Düsseldorf, 1890-1920. New York: Cambridge University Press.

Pew Research Center. 2010. “'Socialism” Not So Negative, “Capitalism” Not So Positive.' 04 May 2010. http://people-press.org/report/610/socialism-capitalism.

Rampell, Catherine. 2009. “'Great Recession”: A Brief Etymology'. New York Times. 11 March. http://economix.blogs.nytimes.com/2009/03/11/great-recession-abrief-etymology/

Rasmussen Report. 2009. 'Just 53\% Say Capitalism Better Than Socialism.' 09 April. http://www.rasmussenreports.com/public_content/politics/general_politics/apr il_2009/just_53_say_capitalism_better_than_socialism

Reich, Robert. 2007. 'How Capitalism is Killing Democracy.' Foreign Policy. Sep/Oct 2007. Issue $162,38-42$.

Scott, Helen (ed). 2008. The Essential Rosa Luxemburg. Chicago: Haymarket.

Selfa, Lance. 2008. The Democrats: A Critical History. Chicago: Haymarket.

Street, Paul. 2010. 'Deepwater Lesson: Expropriate the Expropriators.' MRZine. February 26. http://mrzine.monthleyreview.org/2010/street020610.html

Toussaint, Eric. 1998. Your Money or Your Life! The Tyranny of Global Finance. trans. Raghu Krishnan with Vicki Briault Manus. London: Pluto, and Dar Es Salaam: Mkuki na Nyota Publishers.

Turl, Adam. 2007. 'Is the U.S. becoming post-industrial?' International Socialist Review Issue 52: 46-58. 